\title{
Career Competencies for
} Career Success

\author{
Marinka A. C. T. Kuijpers \\ Birgit Schyns \\ Jaap Scheerens
}

This article addresses the general question as to which competencies employees need to possess in order to engage in self-management in their career development. The authors distinguished and operationalized 6 career factors and competencies of self-management in career development. A quantitative study was performed using 1,579 employees in 16 Dutch companies to investigate the relationship between career competencies and career success. The results indicate that, among others, the factors career control and networking are strongly associated with career success. The results are discussed with respect to the facilitation organizations can provide for their employees' career actualization.

Career development is a field that is becoming increasingly relevant for both employees and employers. Economic and technological developments have resulted in working careers becoming more unpredictable due to changing work opportunities and shifts in labor. A permanent job with one employer, preferably for the entire span of a person's working life, can no longer be considered the normal work pattern. At present, career opportunities tend to be seen in the light of employability (e.g., van Dam, 2004), recognizing that career development frequently goes beyond the boundaries of one organization (so-called boundaryless careers; Arthur, 1994). The notion of a traditional career, chiefly determined by an employee's preliminary training and by opportunities provided by employers, has shifted to the concept of a changing career, largely guided by the employee him- or herself. This change toward employee self-management in career development fuels interest in the personal dispositions that could explain why this type of self-management goes well for some people, but not for others. In this context, we find increasing use of the general term employee competencies. Often lacking, however, is a more specific understanding of which competencies are actually relevant for career development. The need for further research on this matter is underlined by the fact that career competencies are now being mentioned more frequently in national policy documents on employability, as well as in the context of policies and programs in educational and labor organizations. According to Boudreaux (2001) and Savickas

Marinka A. C. T. Kuijpers, Centre for Innovation and Education, The Netherlands; Birgit Schyns and Jaap Scheerens, Department of Educational Organisation and Management, University of Twente, the Netherlands. Birgit Schyns is now at the Department of Human Resource and Marketing Management, University of Portsmouth, United Kingdom. This article is partly based on the first author's dissertation. Correspondence concerning this article should be addressed to Birgit Schyns, University of Portsmouth, Portsmouth Business School, Richmond Building, Portland St., Portsmouth, PO1 3DE, United Kingdom (e-mail: birgit.schyns@port.ac.uk).

(C) 2006 by the National Career Development Association. All rights reserved. 
(2003), studies with practical relevance that go beyond the traditional focus of career development are needed. Thus, our study focuses on the association between career competencies and career success.

\section{Career Competencies}

Career development can be understood as an enumeration of consecutive jobs and training. In line with demands of the modern labor market, there is increased emphasis on the employee's active role and level of involvement with respect to his or her career. This is reflected in concepts such as personal initiative (Frese, 2001), employability (e.g., van Dam, 2004), or preparedness to change (Schyns, 2004). Considering this element of self-guidance, career competencies could be seen as a person's self-management of his or her working and learning experiences in order to achieve desired career progress. Career development is taken as active career-actualization, which we define as the realization of personal goals and values in one's career vis-à-vis the facilitation and constraining conditions of the work situation.

Career competencies are included in various research studies (Arthur, Inkson, \& Pringle, 1999; Ball, 1997; Defillippi \& Arthur, 1994; Eby, Butts, \& Lockwood, 2003; Hackett, Betz, \& Doty, 1985; Jones \& Bergmann Lichtenstein, 2000). However, in these studies, the structure of career competencies remains unclear. On the basis of literature research, qualitative interviews, and factor analyses of data from a large sample, Kuijpers and Scheerens (2006) addressed this point and established a multidimensional assessment of career competencies. They distinguished between six career competencies: career-actualization-ability, the degree to which employees are capable of realizing personal goals and values in their working career; career reflection, reviewing one's own competencies with respect to one's career; motivation reflection, reviewing one's own desires and values with respect to one's career; work exploration, orientation toward matching one's own identity and competencies to the required values and competencies in a specific work situation; career control, career-related planning and influencing of learning and work processes; and networking, setting up contacts that are relevant for one's career (see also Kuijpers, 2005). In our study, we focus on the relationship between these competencies and career success.

\section{Career Competencies and Career_Success}

In this article, we assume that the application of career competencies is related to career success. Career success can be measured in diverse ways. In a recent meta-analysis, $\mathrm{Ng}$, Eby, Sorensen, and Feldman (2005) differentiated between objective and subjective career success, using salary and promotion versus career satisfaction as indicators. Subjective career success has also been defined as the individual's perception of success concerning achievement, future perspectives, recognition, and satisfaction (Nabi, 1999).

In the current study, a distinction is made between intrinsic and extrinsic career success. Intrinsic career success can be compared with subjective 
career success and is based on the person's own appreciation of his or her career actualization. Extrinsic career success relates to external appreciation (salary and occupational status). The following is an outline of how the different career competencies are expected to be related to intrinsic and extrinsic career success.

Career-actualization-ability: Realizing personal goals increases extrinsic career success because the realization of goals will be mirrored in increased salary and high status, assuming that the ambition levels of the goals are high enough.

Career reflection: Reflecting on one's competencies with respect to one's career leads to a realistic image of one's capabilities. Salomone and Slaney (1981) found that $16 \%$ of the male participants and $8.1 \%$ of the female participants in their study named awareness of skills and abilities as having influenced their decision to accept their present job. These percentages were even higher in the context of a satisfying job, namely $17.1 \%$ and $9.9 \%$ for men and women, respectively. We can assume that career reflection will result in career choices that coincide with existing capabilities. Because overly ambitious goals are avoided in this way, we expect that realistic expectations and a higher extrinsic career success will result.

Motivation reflection: Reflecting on one's desires and values will also help with making realistic choices with respect to one's career, especially when motivation reflection is connected to exploring the competencies needed for and values incorporated in certain job opportunities (Meijers, 2002). Both types of behavior are also likely to result in external appreciation (salary and occupational status).

Work exploration: The external appreciation of a person's job, in terms of salary and occupational status, is likely to be enhanced if that person is willing to actively explore how to best use his or her competencies to match the organization's requirements. The importance of a match between the person's values and an organization's values is reflected in research on person-organization fit (e.g., Herriot, 2002).

Career control: Godshalk and Sosik (2003) found that learning-goal orientation, that is, the tendency of individuals to strive for development and learning, is positively related to career satisfaction. Therefore, we assume that career control is related to internal career success. Lifelong learning has become increasingly important in the current labor market situation. Therefore, we expect that individuals who are willing to learn about and train for their desired career will enhance not only their intrinsic career success but also their extrinsic career success (status and salary).

Networking: Forret and Dougherty (2004) found that networking helps in achieving internal and external career success. Therefore, we expect networking to enhance both intrinsic and extrinsic career success.

\section{Personal and Situational Influences} on Career Success

To get a sense of the degree to which career success can be attributed unequivocally to career competencies, it is necessary to rule out other possible determinants of career success. For this purpose, both personal 
background characteristics and contextual, or situational, conditions need to be considered. The relevant literature distinguishes the following set of individual factors: gender, age, position, career ambition (developing capacities, being engaged in a meaningful way, having a good salary, combining work and private life), and mobility ambition (external and internal). We briefly explain how these factors influence career success.

Gender: It seems that men and women differ with respect to their career choices, with women feeling more competent in typically female occupations as opposed to typically male occupations (Betz \& Hackett, 1981). This will influence their career choices. In addition, women and men differ with respect to what determines their career success. Forret and Dougherty (2004) found that for some networking activities, there was a relationship to career success for men but not for women.

Age: In the Netherlands, as well as in other countries, salary increases (more or less automatically) with age. In addition, older persons generally have a higher status in organizations because they have more experience than younger employees. The first point may make it less easy for older employees to change careers because they have more to lose, whereas the second point may make it easier for them to change because they have more to give. This is one way in which age is likely to affect external career success as well as possible career competencies.

Position: We also need to control for the present position in an organization, because this position has implications for salary and status (e.g., Forret \& Dougherty, 2004). Also, employees higher in the organizational hierarchy will generally perceive more career options than will employees on lower levels of the hierarchy.

Career ambition: This is defined as striving to develop capabilities in order to be engaged in a meaningful way, to earn a good salary, and to be able to combine work and private life. We assume that these different targets affect career success in addition to career competencies.

Mobility ambition: Having the ambition to bring about a change needs to be distinguished from the competencies involved in acquiring career success. Whereas competencies refer to behavior and motivations, ambition is the striving for mobility rather than actual behavior. To examine the pure effect of competencies, we needed to control for ambitions in our analyses.

In addition, the following situational factors are important to discuss: mobility perspectives, the dynamics of the work environment (degree of change of activities in the present job and over the past 5 years), and career support from both the work and the private situation (moral support and opportunities to invest in career).

Mobility perspectives: In terms of mobility, some individuals are more likely to be able to move to other jobs. This may be due, for example, to regional differences in the labor market and to restrictions resulting from having a family. In terms of career success, we need to control for mobility perspectives. In this context, Veiga (1983) found that marketability is related to the propensity to move, which in turn will influence how much responsibility a person is able to take for his or her own career. Therefore, we controlled for mobility perspectives in our analysis.

Dynamics of the work environment: This factor is defined as the degree of change of activities in the present job and over the past $\mathbf{5}$ years. Re- 
search has shown that the number of intraorganizational job changes is positively related to external but not to internal career success (Valcour \& Tolbert, 2003). To determine the extent to which competencies are relevant for career success, we controlled for dynamics of the work environment in our analyses.

Career support: Coming from within both the work and the private contexts, career support comprises moral support for and opportunities to invest in one's career. A recent meta-analysis ( $\mathrm{Ng}$ et al., 2005) found that supervisor support is positively related to career satisfaction and salary. In addition, marital status is positively related to satisfaction and promotion ( $\mathrm{Ng}$ et al., 2005) in the sense that people who are married generally have higher job satisfaction and are more often promoted. Therefore, we controlled for career support in our analyses.

All these personal and situational conditions were included in the effort to answer our central research question: Do career competencies explain intrinsic and extrinsic career success, over and above the influence of personal and situational characteristics?

\section{Method}

We conducted a large-scale survey to empirically investigate the relationship between career competencies and career success. The instrument for that study, a self-assessment questionnaire, was distributed among 3,086 employees in 16 Dutch companies. In most companies, employees were randomly chosen from the study's target group (see explanation in the Sample section). This was carried out by means of the SPSS random selection routine. In a few smaller organizations, the personnel manager selected the respondents.

\section{Sample}

The target population was defined as employees in Dutch companies with a minimum educational level of higher education, having at least $\mathbf{l}$ year of work experience, and working a minimum of 20 hours a week. (Note. Higher education refers to tertiary level programs that are less academic than university programs and are not intended to provide access to programs that prepare students for advanced research qualifications.) Of the 3,086 questionnaires, 1,591 (51\%) were returned completed. This realized sample of 1,591 respondents consisted of $68 \%$ men and $32 \%$ women. In the Netherlands, the ratio of men to women who have successfully completed higher education is 60:40 (Centraal Bureau voor Statistiek, 2000). The realized sample roughly corresponds to this ratio. The average age of respondents was 40 years, with a standard deviation of 9.9. Of the total respondent group, $23 \%$ were 30 years old or younger, $44 \%$ were between 30 and 45 , and $33 \%$ were over 45 years of age. Half the respondent group consisted of operational staff, while the other half held an executive position.

We held nonresponse interviews with the 125 employees who failed to return the questionnaire to verify the correspondence between the nonresponse group and the response group on the variables gender, age, position, mobility perspective, and career support from the work situation. The employees from the nonresponse group were selected 
at random. The results revealed no significant differences between the nonresponding and the responding participants. On this basis, we may conclude that the nonresponse group was not selective and that this threat to the generalizability of the results could be ruled out.

\section{Instruments}

Career competencies. The instrument used for collecting data on career competencies was a written self-assessment questionnaire (Kuijpers \& Scheerens, 2006). The instrument comprises six competencies. The response categories range from $\mathrm{l}=$ do not agree at all to $5=$ agree completely. Internal consistencies for the competencies were as follows: career-actualizationability (17 items; $\alpha=.88$ ), career reflection ( 5 items; $\alpha=.80$ ), motivation reflection ( 8 items; $\alpha=.83$ ), work exploration ( 6 items; $\alpha=.75$ ), career control ( 14 items; $\alpha=.84$ ), networking ( 4 items; $\alpha=.74$ ).

Extrinsic career success was assessed using two indicators: salary and occupational status (three items, $\alpha=.61$ ). Both indicators were assessed as self-report data. Intrinsic career success was assessed using a six-item scale for career actualization success. The response categories ranged from $1=$ not satisfactorily to $4=$ very satisfactorily. Cronbach's alpha for this instrument was .76.

Personal and situationally linked variables. The participants were asked to indicate their gender, age, and position. Career ambition was assessed using one item referring to different career goals. Mobility ambition was assessed using one item referring to different types of ambition (i.e., upward external and upward internal). Mobility perspectives were assessed using the individual score on the self-assessment questionnaire on the six career competencies and two scores regarding mobility perspectives and other mobility figures that were derived from classifications of the organization with which the participants worked. The assessment refers to chances of and plans for mobility. Dynamics of the work environment were assessed using one item with response categories ranging from $1=$ bardly ever to $4=$ monthly or even more often, exploring the frequency of change in tasks in the actual position of the participants. Career support from the work context was assessed using one self-report item and one item supplied by the organization. The assessment refers to work and learning experience as well as networks provided by the organization. Career support from private contexts was assessed using two self-report items referring to moral support (career support at home) as well the possibility of making financial and monetary investments in one's career (investment possibilities private; intercorrelation .54).

\section{Analyses}

To investigate whether career competencies contributed to the explained variance in career success, regression analyses were carried out with internal and external career success as the dependent variables and the six career competencies as the independent variables. The individual and situational variables (gender, age, position, career ambition, mobility ambition, mobility perspectives, dynamics of the work environment, and career support from the work context and career support from the private context) were controlled for. 


\section{Results}

This section presents the results of the regression analyses used to assess the contribution of career factors to career success, when controlling for relevant personal and situationally linked variables. The predictor variables were simultaneously entered in the regression model. Table 1 displays which variables contributed significantly to the explained variance in internal career success.

Together the variables explained $35 \%$ of the variance in intrinsic career success (see $R^{2}$ in Table 1 ). After controlling for the previously mentioned variables, analyses indicated that career-actualization-ability, career control, and networking had a significant and positive impact on career success. Motivation reflection had a significant effect as well; however, in contrast to our expectations, this effect was negative. Furthermore, the control variables age, position, mobility ambition, mobility possibilities, intention for external mobility, and dynamics of the present job appeared to be significantly related to intrinsic career success. In addition, the other two variables that contributed significantly to explaining the variance of intrinsic career success were career support at work and career support at home.

Career-actualization-ability and networking both contributed positively to the external career success that respondents experienced (Table 2), whereas motivation reflection proved again to be negatively related to this variable. In addition, mobility ambition, intention for mobility, dynamics

TABLE 1

\section{Multiple Regression Analysis With Career Actualization Success as a Dependent Variable}

\begin{tabular}{|c|c|c|c|}
\hline Variable & B & $\beta$ & $R^{2}$ \\
\hline Constant & $2.48^{\star \star \star \star}$ & & .35 \\
\hline Gender & 0.01 & .01 & \\
\hline Age & -0.001 & $-.12^{\star \star \star}$ & \\
\hline Position: Managerial & 0.23 & $.20^{\star *}$ & \\
\hline Career ambition: Good salary & 0.02 & .02 & \\
\hline Career ambition: Meaningful task & 0.03 & .03 & \\
\hline Career ambition: Developing capabilities & 0.04 & .04 & \\
\hline Mobility ambition: Upward external & -0.10 & $-.09^{\star \star}$ & \\
\hline Mobility ambition: Upward internal & -0.01 & -.01 & \\
\hline Mobility possibilities & 0.09 & $.09^{\star \star}$ & \\
\hline Intention for internal mobility & -0.04 & -.04 & \\
\hline Intention for external mobility & -0.15 & $-.16^{* \star \star}$ & \\
\hline Dynamics of present job & 0.10 & $.11^{* * *}$ & \\
\hline Dynamics in past 5 years & 0.02 & .03 & \\
\hline Career support at work & 0.22 & $.23^{\star \star \star}$ & \\
\hline Career support at home & 0.07 & $.07^{*}$ & \\
\hline Investment possibilities private & -0.02 & -.02 & \\
\hline Career-actualization-ability & 0.17 & $.15^{\star \star \star}$ & \\
\hline Career reflection & -0.002 & -.05 & \\
\hline Motivation reflection & -0.06 & $-.08^{\star}$ & \\
\hline Work exploration & -0.03 & -.06 & \\
\hline Career control & 0.10 & $.11^{* \star}$ & \\
\hline Networking & 0.07 & $.11^{\star \star}$ & \\
\hline
\end{tabular}

Note. Dynamics = dynamics of the work environment.

${ }^{\star} p<.05 .{ }^{\star \star} p<.01 .{ }^{\star \star \star} p<.001$. 


\section{Multiple Regression Analysis With External Appreciation as a Dependent Variable}

\begin{tabular}{|c|c|c|c|}
\hline Variable & $B$ & $\beta$ & $R^{2}$ \\
\hline $\begin{array}{l}\text { Constant } \\
\text { Gender } \\
\text { Age } \\
\text { Position: Managerial } \\
\text { Career ambition: Good salary } \\
\text { Career ambition: Meaningful task } \\
\text { Career ambition: Developing capabilities } \\
\text { Mobility ambition: Upward external } \\
\text { Mobility ambition: Upward internal } \\
\text { Mobility possibilities } \\
\text { Intention for internal mobility } \\
\text { Intention for external mobility } \\
\text { Dynamics of present job } \\
\text { Dynamics in past } \\
\text { Career support at work } \\
\text { Career support at home } \\
\text { Investment possibilities private } \\
\text { Career-actualization-ability } \\
\text { Career reflection } \\
\text { Motivation reflection } \\
\text { Work exploration } \\
\text { Career control } \\
\text { Networking }\end{array}$ & $\begin{array}{r}1.81^{* * *} \\
-0.05 \\
0.00 \\
0.06 \\
-0.03 \\
0.02 \\
0.03 \\
-0.17 \\
-0.16 \\
0.04 \\
0.01 \\
-0.12 \\
0.07 \\
0.07 \\
0.14 \\
0.05 \\
-0.01 \\
0.07 \\
-0.00 \\
-0.06 \\
-0.03 \\
0.01 \\
0.05\end{array}$ & $\begin{array}{l}-.06 \\
.01 \\
.06 \\
-.04 \\
.23 \\
.04 \\
-.18^{\star \star \star} \\
-.17^{\star \star \star} \\
.05 \\
.02 \\
-.14^{\star \star \star} \\
.08^{\star \star} \\
.07^{\star} \\
.16^{\star \star \star} \\
.05 \\
-.01 \\
.08^{\star} \\
-.01 \\
-.09^{\star} \\
-.05 \\
.01 \\
.09^{\star}\end{array}$ & .16 \\
\hline
\end{tabular}

Note. Dynamics $=$ dynamics of the work environment.

${ }^{*} p<.05 .{ }^{* *} p<.01{ }^{\star \star \star} p<.001$.

of present job, and career support at work had a significant impact on external career success.

\section{Summary and_Discussion}

The aim of the current study was to address the relationship between career competencies and career success. Which career competencies explain intrinsic and extrinsic career success, over and above the variables of personal and situational influences? The variance in intrinsic carcer success could be explained to $35 \%$ by the variables included in the regression analysis. The career factors that explain variance in intrinsic career success appear to be career-actualization-ability, career control, and networking. Conversely, motivation reflection proved to correlate negatively with intrinsic as well as extrinsic career success. This means that employees who examine whether their job corresponds with their personal values experience less career success than do those who do not examine their job in this way. It is conceivable that having little career success urges a person to reflect on his or her motives. Those dissatisfied with their career success could be more aware of the discrepancy between their preferences and the realization of these preferences in their work, and perhaps they therefore see no opportunities for bringing about change because of constraining personal or situational factors, such as diminished opportunities for mobil- 
ity. They might also be insufficiently able to steer their career in a different direction through career control and networking. An explanation for the unexpected result with respect to external career success might be that employees who try to find a job corresponding to their personal values and interests are less concerned with external appreciation. For professional counselors involved in providing career development services, the results suggest that the focus of career guidance should not be on reflection, which according to our results is negatively related to career success, but rather on career control and networking.

In contrast to our expectations, career reflection produced no significant contribution to the explained variance in intrinsic career success. It could be that our respondents were beyond this stage in their careers and that reflection on capacities is more important in earlier stages, that is, in job searching behavior.

Among the situational variables, career support at work showed the largest contribution to the explained variance in intrinsic career success. This supports the findings of Rowden (2002). Furthermore, other situational factors that might be important for a modern career, that is, opportunities for mobility, the dynamics of the present job, and moral support in the private context, proved to contribute positively to the explained variance in intrinsic career success. Employees in a managerial position experience more intrinsic career success.

In terms of demographic variables, there were no significant differences between men and women. Age proved to correlate negatively with intrinsic career success. The older the respondents, the less career success they experienced. Career ambition had no significant influence; however, an ambition for external mobility and intention for external mobility correlated negatively with intrinsic career success. This unexpected result may be due to unrealistic expectations, in the same way that Nabi (1999) interpreted the negative relationship between ambition and subjective career success.

The conclusion drawn by Swaen, Kant, van Amelsvoort, and Beurskens (2002), that employees who experienced more dynamics in their previous job had less job satisfaction, was not supported in this study. We found that dynamic environment was positively related to intrinsic career success. Employees who experienced career support at work also had more intrinsic and external career success. This implies that organizations have the opportunity to affect the career success of employees by actively supporting the career actualization of employees and by offering opportunities to change work content. In this sense, organizations can make a difference in career development.

\section{Limitations}

Although our sample was relatively large, making the results less prone to generalization problems, our study did have some limitations. All data were collected from the same source and were collected at one point in time. The latter means that we cannot unequivocally determine the direction of relationships we found, although based on prior research and theory, the direction from competencies to career success seems more logical. 


\section{Conclusion}

Our aim was to shed light on how competencies affect career success. As mentioned in the introduction, the importance of our results in terms of today's labor market cannot be underestimated. In contrast to prior generations, today's employees are responsible for their own careers and can no longer rely on lifelong employment in one organization. In addition, even when being employed in one organization for a longer period of time, more changes in the job tasks and the environment are experienced than was the case for employees in the past. In terms of helping employees to achieve career success, our results show that the desires and plans of employees are crucial. In counseling, these aspects should therefore be of primary focus. Although careers are more in the hands of employees these days, employers may want to support their staff in their career development. Our results suggest ways in which organizations can support their employees in their efforts to achieve career success. In addition to personal characteristics, such as motivation reflection and networking, career support from the work situation and a dynamic work environment are related to both internal and external career success.

\section{References}

Arthur, M. B. (1994). The boundaryless career: A new perspective for organizational inquiry. Journal of Organizational Behaviour, 15, 295-306.

Arthur, M. B., Inkson, K., \& Pringle, J. K. (1999). The new carecrs. Individual action and economic change. London: Sage.

Ball, B. (1997). Career management competencies-the individual perspective. Career Development International, 2, 74-79

Betz, N. E., \& Hackett, G. (1981). The relationship of career-related self-efficacy expectations to perceived career options in college women and men. Journal of Counselling Psychology, 28, 399-410.

Boudreaux, M. A. (2001). Career development: What is its role in human resource development? In O. A. Aliaga (Ed.), Academy of Human Resources Development 2001 conference proceedings (pp. 805-812). Bowling Green, OH: Bowling Green State University.

Centraal Bureau voor Statistiek. (2000). Berocpsbevolking; naar geslacht (Working people according to their sex). Retrieved October, 5, 2006, from http://statline.cbs.nl/ StatWeb/table. asp?STB $=$ Gl \&LA $=n 1 \& D M=S L N L \& P A=37940 \& D l=0 \& D 2=0,16$ $22 \& D 3=a \& D 4=a \& L Y R=G 3: 10, T: 0 \& H D R=G 2$

Defillippi, R. J., \& Arthur, M. B. (1994). The boundaryless career: A competency-based perspective. Journal of Organizational Behavior, 15, 307-324.

Eby, L. T., Butts, M., \& Lockwood, A. (2003). Predictors of success in the era of the boundaryless career. Journal of Organizational Bebavior, 24, 689-708.

Forret, M. L., \& Dougherty, T. W. (2004). Networking behaviors and career outcomes: Differences for men and women? Journal of Organizational Behavior, 25, 419-437.

Frese, M. (2001). Personal initiative (PI): The theoretical concept and empirical findings. In M. Erez, M. Kleinbeck, \& H. Thierry (Eds.), Work motivation in the context of a globalizing economy (pp. 99-110). Mahwah, NJ: Erlbaum.

Godshalk, V. M., \& Sosik, J. J. (2003). Aiming for career success: The role of learning goal orientation in mentoring relationships. Journal of Vocational Behavior, 63, 417-437.

Hackett, C. T., Betz, N., \& Doty, M. (1985). The development of a taxonomy of career competence for professional women. Sex Roles, 12, 393-409. 
Herriot, P. (2002). Selection and the self: Selection as a social process. European Journal of Work and Organizational Psychology, 11, 385-402.

Jones, C., \& Bergmann Lichtenstein, B. M. (2000). The "architecture" of careers: How career competencies reveal firm dominant logic in professional services. In M. A. Peiperl, M. B. Arthur, R. Goffec, \& T. Morris (Eds.), Career frontiers: New conceptions of working lives (pp. 153-176). Oxford, England: Oxford University Press.

Kuijpers, M. A. C. T. (2005). Loopbaan en loopbaansucces. Tijdschrift voor $H R M, 8(2)$, 85-95.

Kuijpers, M. A. C. T., \& Scheerens, J. (2006). Career competencies for the modern career. Journal of Career Development, 32, 303-319.

Meijers, F. (2002). Career learning in a changing world: The role of emotions. International Journal for the Advancement of Counselling, 24, 149-167.

Nabi, G. R. (1999). An investigation into the differential profile of predictors of objective and subjective career success. Career Development International, 4, 212-224.

Ng, T. W. H., Eby, L. T., Sorensen, K. L., \& Feldman, D. C. (2005). Predictors of objective and subjective career success: A meta-analysis. Personnel Psychology, 58, 367-408.

Rowden, R.W. (2002). The relationship between workplace learning and job satisfaction in U.S. small to mid-sized businesses. In T. M. Egan \& S. A. Lynham (Eds.), Academy of Human Resource Development 2002 Conference Proceedings, Vol. 1 (pp. 117-124). Bowling Green, $\mathrm{OH}$ : Bowling Green State University.

Salomone, P. R., \& Slaney, R. B. (1981). The influence of chance and contingency factors on the vocational choice process of nonprofessional workers. Journal of Vocational Behavior, 19, 25-35.

Savickas, M. L. (2003). Advancing the career counseling profession: Objectives and strategies for the next decade. The Career Development Quarterly, 52, 87-96.

Schyns, B. (2004). The influence of occupational self-efficacy on the relationship of leadership behavior and preparedness for occupational change. Journal of Career Development, 30, 247-261.

Swaen, G. M. H., van Kant, I. J., Amelsvoort, L. G. P. M., \& Beurskens, A. J. H. M. (2002). Job mobility, its determinants, and its effect: Longitudinal data from the Maastricht Cohort Study. Journal of Occupational Health Psychology, 7, 121-129.

Valcour, P. M., \& Tolbert, P. S. (2003). Gender, family and career in the era of boundarylessness: Determinants and effects of intra- and interorganizational mobility. International Journal of Human Resource Management, 14, 768-787.

Van Dam, K. (2004). Antecedents and consequences of employability orientation. European Journal of Work and Organizational Psychology, 13, 29-51.

Veiga, J. F. (1983). Mobility influences during managerial career stages. Academy of Management Journal, 26, 64-85. 
Copyright of Career Development Quarterly is the property of National Career Development Association and its content may not be copied or emailed to multiple sites or posted to a listserv without the copyright holder's express written permission. However, users may print, download, or email articles for individual use. 